PERIODICALS OF ENGINEERING AND NATURAL SCIENCES

Vol. 5 No. 1 (2017) - Special Issue (Recent Topics in Environmental Science)

Available online at: http://pen.ius.edu.ba

\title{
The Potential of Solar Energy for Sustainable Water Resource Development and Averting National Social Burden in Rural Areas of Zambia
}

\author{
Mabvuto MWANZA \\ Solar Energy \\ Institute, Ege \\ University, Izmir \\ Turkey
}

\author{
Mwansa KAOMA \\ School of Engineering, \\ University of Zambia, \\ Lusaka, Zambia
}

\author{
Chilala K.BOWA \\ Faculty of Engineering \\ And BuiltEnvironment \\ University of \\ Johannesburg, \\ South Africa
}

\author{
Numan S.ÇETIN \\ Solar Energy \\ Institute, Ege \\ University, Izmir \\ Turkey
}

\author{
Koray ÜLGEN \\ Solar Energy \\ Institute, Ege \\ University, Izmir \\ Turkey
}

\begin{abstract}
About 50\% of the Zambia's population in the rural areas do not have access to an improved source of water supply, thus relies on untreated water from shallow wells, streams and rivers for drinking and other activities. The lack of access to clean water is associated with water related illnesses and other negative social impacts. This paper aimed to propose use of solar energy in water pumping systems for water supply in rural areas of Zambia. The information used is from secondary sources. Use of the solar energy in water pumping system is not only an important part of providing household with clean drinking water alternative, but also important for access to an improved source of water supply for rural households and sustainable water resource development in Zambia. The paper further investigates the potential of using solar energy in water pumping system to avert the nation's disease burden and its sustainability using number of employment created as indicator. The analyzed results indicate that the use of solar energy in water pumping systems have the potential of reducing the Zambia's social cost burden by $30 \%$ which translate to about US\$61million saving per year and can create employment of about 24,000 in Zambia.
\end{abstract}

country.

Keywords: PV water pumping system; solar energy; Photovoltaic; Water; Sustainable water development,

\section{Introduction}

Zambia is located in the heart of Southern Africa between latitudes 8 and 18 degrees south of the equator. Over $98.77 \%$ of Zambia's surface is taken up by land leaving only $1.23 \%$ covered by surface water such as rivers, streams, lakes and other inland water (Source). It has no access to the sea or ocean. The country is surrounded by eight neighboring countries namely; Tanzania and Democratic Republic of Congo (DR Congo) to the North, Angola to the West and Namibia to the South West; Botswana and Zimbabwe to the South; and Mozambique and Malawi to the east as shown in fig.1 [1,2]. It has a population of approximately 15.5 million people (2015 estimates) of which $58 \%$ live in rural areas and $42 \%$ in urban areas $[1,3,4]$. According to UNICEF data, the level of access to improved source of water supply in Zambia for the whole population is about $64 \%$ and $50 \%$ for access to adequate sanitation [5]. However, only 55,3\% of the rural populations have access to improved source of water supply and adequate sanitation [6]. The country has favorable climate with average sunshine of about 6- 8hours per day throughout the country with monthly average of daily solar irradiation of $5.5 \mathrm{kWh} / \mathrm{m} 2 /$ day throughout the year. Such irradiation is adequate for using solar energy technologies such as Photovoltaic water pumping systems [7]. The supply of clean and reliable water and reduction in distance to water supply source in rural areas is vital for the life of the community, livestock and agriculture. The use of solar energy in water pumping system is one of the best alternative solutions for rural areas that are located far from the electric grid since the solar energy resource is readily available in the communities.

The aim of the study is to assess the potential of solar energy in averting the water borne disease burden in the rural areas of Zambia, through improved access to safe clean water supply sources by using solar energy in water pumping systems. This desktop study involved collecting data from various literatures. 


\section{Water Situation in Zambia}

\subsection{Water Resources}

The country has adequate water resources as compared to other countries in the region with water surface area of about $9,220 \mathrm{~km}^{2}$. It is rich in lakes such as Lake Mweru, Bangweulu, and Tanganyika and manmade lakes of Kariba and Itezhi-Tezhi, and rivers like Zambezi, Kafue, Luapula, Chambeshi, and Luangwa as shown in figure 1[2]. Table 1 shows statistics on the river catchment areas of some rivers and lakes in Zambia [2]. However, despite rich in water resources the availability of water in the country, the surface water is not evenly distributed as shown in fig.1, and the access to safe clean water by the rural population is low. The country has average annual rainfall ranging between $600 \mathrm{~mm}$ in the south and 1, 500 $\mathrm{mm}$ in the north $[2,6]$.

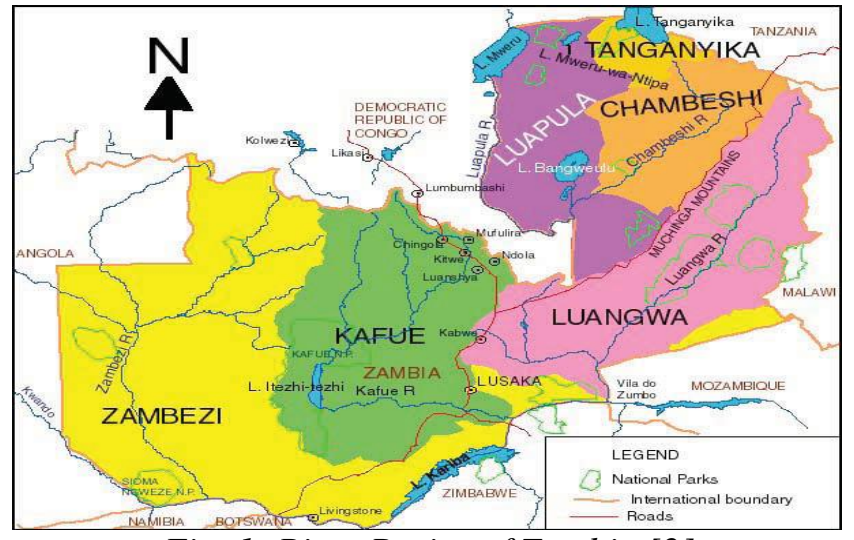

Fig. 1: River Basins of Zambia [2]

Table 1: Percentage Contribution of Rivers and Lakes to Water Resource [2]

\begin{tabular}{|l|c|c|c|}
\hline River/Lake & $\begin{array}{c}\text { Total } \\
\text { Area(km }\end{array}$ & $\begin{array}{c}\text { Contribution to } \\
\text { Surface water } \\
\text { Potential (\%) }\end{array}$ & $\begin{array}{c}\text { Annual } \\
\text { Run-Off } \\
\mathbf{( k m}^{\mathbf{3}} \mathbf{( \mathbf { m }}\end{array}$ \\
\hline Zambezi & 803,267 & 36,36 & 41,75 \\
\hline Luapula & 268,235 & 26,25 & 30,14 \\
\hline Luangwa & 144,358 & 19,44 & 22,32 \\
\hline Chambeshi & 44,427 & 7,62 & 8,75 \\
\hline Kafue River & 156,995 & 8,40 & 9,88 \\
\hline Tanganyika & 15,856 & 1,73 & 1,99 \\
\hline $\begin{array}{l}\text { Total for } \\
\text { Zambia }\end{array}$ & 803,267 & 99,8 & 114,830 \\
\hline
\end{tabular}

(Source: Ministry of Energy and Water Development)

\subsection{Water Quality}

The water quality in Zambia is generally good, however due to increase in population since independence this have resulted in increasing pressure on the water resource. As the results of human activities and ever increasing population in the country the water quality has generally reduced [2,6]. According to the World Health Organization 2013 report, water pollution of drinking water in most developing countries like Zambia are due to poor sewerage disposal, such as use of pit latrines for toilets in many rural and sub-urban areas and lack of access to clean water [8]. When pit latrines are used for toilets, the wastes are kept in the toilets holes because there is no sewerage system for disposing off the wastes far from the residential areas, thus during rain seasons, the polluted water from the toilets are gradually washed into the nearby groundwater or surface waters. This leads to affecting the environments and leads to water related diseases such as dysentery, cholera, diarrhea, and many other kinds of illnesses related to drinking untreated water from shallow wells in many rural areas.

\subsection{Access to Safe Water}

Zambia's total annual water consumption is just under $40 \mathrm{~km}^{3}$ per year with hydropower generation taking the largest amount of water followed by agriculture, industry, drinking water and domestic water supply as shown in figure $3[2,6]$. The government is facing with the challenge of satisfying 4,8 million people without access to safe water and 6,6 million people without access to adequate sanitation facilities [2,5]. This has been due to lack of investment in the water and sanitation infrastructure by the government and also because of the settlement patterns in the country $[2,9]$. As the result, there is low rate of access to water supply and sanitation especially in rural areas where the majority of the population lives as shown in table 2 section 3 below. Therefore, most people in these areas use untreated shallow water wells for their household water needs. However, the uses of these untreated water resources are mostly related to water borne related illness. Table 3 below in section 3 show the national outpatient and admission cases due to water borne related diseases due to lack of access to safe clean water and sanitation.

The government of Zambia stated a standard for access to domestic water supply which was set at $500 \mathrm{~m}$ and each water point is supposed to serve about 200 people $[2,9]$. These set standards can easily be achieved by use of solar energy technologies in water pumping systems in rural communities far from the grid.

\section{PV Water Pumping System}

A photovoltaic water pumping system is a water pumping system that uses solar energy as the primary energy source for pumping water. In these systems, the photovoltaic cells are used to convert solar energy into electrical energy, which is then used by the motorpump unit for pumping water. This system offers best alternative solution for rural areas far from electric grid for pumping and supplying clean and improved water to the communities. In these systems water is usually pumped during the day and kept in water tanks for treatment and use during day time, night or under cloud cover [12]. 
Access to water supply in rural areas in many developing countries such as Zambia (for household, livestock and irrigation use) is very difficult and time consuming [13]. This is because people have to walk for long distances to draw water from rivers, streams, shallow wells, or boreholes that are usually located far from the communities [14]. Thus, water pumping systems that use solar energy are the best alternative solutions for rural areas for improved access to clean water supply source $[14,15]$. Typical Stand-alone solar water pumping systems generally consist of PV array, power conditioning unit, motor-pump unit, and water tank. The use of PV water pumping system in rural areas can greatly contribute to the development of the rural areas as it has potential for not only pumping and supplying water to the communities but also creating employment and reducing the use of untreated shallow water sources, thus, reducing the water borne related diseases such as mentioned in table 3 .

\section{Materials and Methods}

This section shows the summary of the data considered for the investigation, the results and brief discussion of the results. In the study, polycrystalline PV module has been considered with the following specifications; PV power 250WP, Voltage VMPP $30.3 \mathrm{~V}$, operating current IMPP 8.25 and PV module area of $1.64 \mathrm{~m} 2$ [24]. The monthly averages of daily solar irradiation for the study area have been extract from the NASA Surface Meteorology and Solar Energy. Table 4 contains the input parameters used for sizing a PV water pumping system for each serving point using the above equations above. In this study, only the direct employment at each serving point has been considered. Furthermore, in calculation of saving on social burden cost, the assumption was access to safe clean water reduces the water related diseases by $30 \%$ which was according to the study carried out by Esrey, S.A. The data used to estimate the cost of social burden was according to the study carried out in Zambia by Lumbwe Chola as shown in Table 5.

In order to investigate the potential of using solar energy in water pumping system to avert the nation's disease burden and its sustainability, the number of employment created has been used as indicator at $100 \%$ access to safe and clean water. According to the Zambian standards the average family size is 5 [1] and the average amount of water required per person per day in this study has been assumed to be 40 liters per day. According to the government of Zambia, the standard access point to domestic water supply is set at 500 meters from the furthest house and each water point is suppose to serve about 200 people [2,9]. Furthermore, according to [26] the cost of water on average is $\$ 0.25 / \mathrm{m}^{3}\left(0-6 \mathrm{~m}^{3}\right)$ and the annual average of daily solar energy is $6,37 \mathrm{kWh} / \mathrm{m}^{2}$-day $[7,25]$.

The components efficiency and factors considered in this study have been extracted from various literatures: Inverter MPPT set efficiency of 98\% [24], Motor-Pump set efficiency of $42 \%[18,23]$, cable losses $2 \%$ and PV other losses $10 \%$ [23].

Table 2: Summary of Access to Safe Water Supply and Sanitation in Zambia (Source: 2013,2014, NWASCO reports $[4,5,9,11])$

\begin{tabular}{|c|c|c|c|c|c|c|c|c|c|}
\hline & \multicolumn{3}{|c|}{2012} & \multicolumn{3}{|c|}{2013} & \multicolumn{3}{|c|}{2014} \\
\hline & \multirow[t]{2}{*}{ Population } & \multicolumn{2}{|c|}{ Coverage (\%) } & \multirow[t]{2}{*}{ Population } & \multicolumn{2}{|c|}{ Coverage (\%) } & \multirow[t]{2}{*}{ Population } & \multicolumn{2}{|c|}{ Coverage (\%) } \\
\hline & & SW & $\mathbf{S}$ & & SW & $\mathbf{S}$ & & SWS & $\mathbf{S}$ \\
\hline Zambia & $13,817,480$ & 68,5 & 41,9 & $14,222,230$ & 72,3 & 47,8 & $14,638,510$ & 67,2 & 54,9 \\
\hline Urban & $5,760,541$ & 81,8 & 57,3 & $5,965,575$ & 83,9 & 58,7 & $6,122,284$ & 83,8 & 60,7 \\
\hline Rural & $8,056,939$ & 59,0 & 31,0 & $8,256,655$ & 64,0 & 40,0 & $8,516,226$ & 55,3 & 50,8 \\
\hline
\end{tabular}

*SW-Safe Water Supply, S-Sanitation (Source: 2013,2014, NWASCO reports[4,5,9,11])

Table 3: Water Borne Related Disease Cases

\begin{tabular}{|c|c|c|c|c|c|c|}
\hline \multirow{3}{*}{ Disease Description } & \multicolumn{6}{|c|}{ Year } \\
\hline & \multicolumn{2}{|c|}{2010} & \multicolumn{2}{|c|}{2011} & \multicolumn{2}{|l|}{2012} \\
\hline & Outpatient & Admission & Outpatient & Admission & Outpatient & Admission \\
\hline Typhoid Cases & 977 & 37 & 2,657 & 101 & 2,433 & 93 \\
\hline Severe Diarrheal (with Dehydration) Cases & 1,546 & 59 & 25,742 & 982 & 29,948 & 1,143 \\
\hline Cholera Cases & 8,893 & 339 & 796 & 30 & 483 & 18 \\
\hline Dysentery Cases & 60,327 & 2,302 & 64,525 & 2,463 & 56,902 & 2,172 \\
\hline Diarrheal Non-Blood Cases & $1,038,596$ & 39,640 & $1,127,520$ & 43,033 & $1,148,832$ & 43,847 \\
\hline Total Cases & $1,110,338$ & 42,378 & $1,221,239$ & 46,610 & $1,238,598$ & 47,273 \\
\hline Total Population & \multicolumn{2}{|c|}{$13,460,310$} & \multicolumn{2}{|c|}{$13,881,340$} & \multicolumn{2}{|c|}{$13,817,480$} \\
\hline Percentage (\%) & 8,25 & 0,31 & 8,80 & 0,34 & 8,96 & 0,34 \\
\hline
\end{tabular}

(Source: Ministry of Health, Planning and Policy Department [9,10])

Table 4: PV Water Pumping System Sizing Parameters

\begin{tabular}{|l|c|}
\hline Parameter & Quantity \\
\hline Average water required per person per day & $0.04 \mathrm{~m} 3 /$ day \\
\hline Average Borehole Depth & $30 \mathrm{~m}$ \\
\hline
\end{tabular}




\begin{tabular}{|c|c|}
\hline Tank Height from ground level & $10 \mathrm{~m}$ \\
\hline \multirow[t]{3}{*}{ Annual Monthly solar radiation } & Maximum Radiation: $7.23(\mathrm{kWh} / \mathrm{m} 2 /$ day $)$ \\
\hline & Average Radiation: $6.37(\mathrm{kWh} / \mathrm{m} 2$ /day) \\
\hline & Minimum Radiation: $5.19(\mathrm{kWh} / \mathrm{m} 2 /$ day $)$ \\
\hline Location & 15057'40'’ S, 26022'1'’E \\
\hline Optimal Inclination Angle & 210 \\
\hline Number of people at each serve point & 200 (40 house, 5 people per house on average) \\
\hline Specific Pumping time (average sunshine time ) & $6 \mathrm{hrs}$ \\
\hline Autonomy period & 3Days \\
\hline
\end{tabular}

Table 5: Cost of Treatment for Water Borne Related Diseases [9,10]

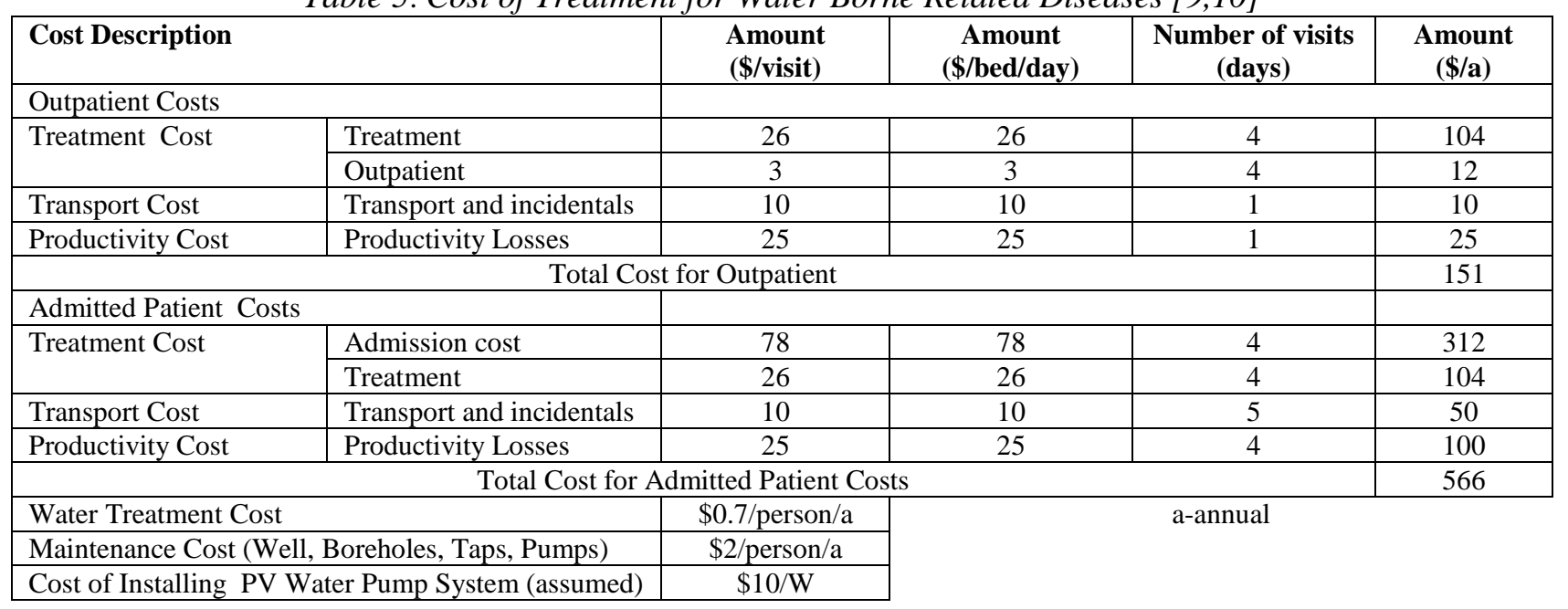

\section{Theory/Calculation}

\subsection{Amount of Water Required}

The amount of water required $V_{t}$ to be supplied at each serving point per day, has been determined in terms of water required per person per day $\mathrm{V}_{\mathrm{p}}$ and the number of people at the serving point $\mathrm{N}_{\mathrm{p}}$. Therefore, the volume of water $\mathrm{V}\left(\mathrm{m}^{3}\right)$ in a tank that is required to supply each serving point for any number of autonomy days has been determined by $[14,17]$.

$$
V_{t}=N_{P} \cdot V_{P} T_{D}
$$

Where Vt is total amount of water required to be pumped per day $\left(\mathrm{m}^{3}\right), \mathrm{Np}$ is total number of people at serving point, $\mathrm{Vp}$ is total amount of water per person per day $\left(\mathrm{m}^{3}\right)$, and $\mathrm{T}_{\mathrm{D}}$ is number of autonomy days $(3$ days in this case study).

The pumping rate which is also called water flow rate has been estimated using the average number of peak sunlight hours and the total amount of water required to be pumped per day using the equation given below $[14,18]$.

$$
Q=v \cdot A=\frac{V_{t}}{\boldsymbol{t}_{T}}
$$

Where $\mathrm{Q}$ is pumping rate $(\mathrm{m} 3 / \mathrm{s})$ or $(\mathrm{m} 3 / \mathrm{hr}), \mathrm{t}_{\mathrm{T}}$ is number of sunlight hours or the total pumping time $(\mathrm{hr}), \mathrm{v}$ is velocity of water $(\mathrm{m} / \mathrm{s}), \mathrm{A}$ is cross-section area of the pipe $\left(\mathrm{m}^{2}\right)$, and $\mathrm{Vt}$ is total amount of water required per day per serving point $\left(\mathrm{m}^{3}\right)$.

\subsection{Pumping Head}

The total dynamic head TDH is the sum of suction head $\mathrm{H}_{\mathrm{SH}}$, discharge head $\mathrm{H}_{\mathrm{DH}}$ and total frictional head losses $\mathrm{H}_{\mathrm{HL}}$ [18]. Assuming only 5\% friction head losses should be allowed in the system the total dynamic head has been determined using eq. $3[18,19]$

$$
H_{T D H}=1,05\left(H_{S H}+H_{D H}\right) .
$$

Where $\mathrm{H}_{\mathrm{TDH}}$ is total dynamic head (m), $\mathrm{H}_{\mathrm{SH}}$ is suction head $(\mathrm{m})$, and $\mathrm{H}_{\mathrm{DH}}$ is discharge head (m).

\subsection{Pump Hydraulic Power}

The energy required by the motor-pump set depends on the efficiency of both the motor and the pump. However, the efficiency of subsystem depends on the efficiencies of motor-pump set, cables, other electronic components and inverter-MPPT system, these efficiencies translate into the total subsystem efficiency used to determine the total energy required per day. The power delivered by the pump to the fluid called hydraulic power which is required per day to supply volume of water $\mathrm{Vt}\left(\mathrm{m}^{3}\right)$ at total dynamic head $\mathrm{H}_{\mathrm{TDH}}$ has been determined using eq. $4[12,18,20]$. 


$$
P_{h y d}=\frac{\rho g Q H_{T D H}}{1000}
$$

Where $P_{\text {hyd }}$ is Hydraulic power delivered by the pump to water $(\mathrm{kW}), \rho$ is water density $(1000 \mathrm{~kg} / \mathrm{m} 3)$, $\mathrm{g}$ is acceleration due to gravity $\left(9.81 \mathrm{~m} / \mathrm{s}^{2}\right), \mathrm{H}_{\mathrm{TDH}}$ is total dynamic head $(\mathrm{m})$, and $\mathrm{Q}$ is water flow rate $\left(\mathrm{m}^{3} / \mathrm{s}\right)$. The subsystem efficiency is given as:

$$
\eta_{\text {subsyst }}=\eta_{m p} \eta_{c} \eta_{p c u}
$$

Where $\eta_{\text {subsystem }}$ is efficiency of the subsystem, $\eta_{\text {pcu }}$ is efficiency of power condition Units and other electronics, $\eta_{c}$ is efficiency of Cables, and $\eta_{m p}$ is efficiency of Motor-Pump set.

The total energy $\mathrm{E}_{\mathrm{T}}(\mathrm{kWh})$ that has to be supplied to the subsystem for the specific period of time $t_{T}$ called specific pumping time has been determined using eq. 6 .

$$
E_{T}=\frac{P_{\text {hyd }} t_{T}}{\eta_{\text {subsyst }}}
$$

\subsection{PV Generator Sizing}

In order to determine the size of the PV generator and the number of PV panels required for the system. Firstly, it is important to determine the required PV area $A_{P V}\left(m^{2}\right)$ from the worst case minimum monthly average of daily solar radiation, $\mathrm{H}\left(\mathrm{kWh} / \mathrm{m}^{2}\right.$-day), the PV module laboratory efficiency $\eta_{\mathrm{PV}, \mathrm{u}}$ and the operating efficiency of the PV module, and has been estimated using the eqs.7,8,9,10 and 11 given below $[14,22,23]$. PV module laboratory efficiency $\eta_{\mathrm{PV}, \mathrm{u}}$ has been determined using eq. 7 .

$$
\eta_{\text {PVöu }}=\frac{V_{M P P} I_{M P P}}{1000 A_{P V o ̈ u}}
$$

Where $\mathrm{V}_{\mathrm{MPP}}$ is PV module Voltage $(\mathrm{V}), \mathrm{I}_{\mathrm{MPP}}$ is PV module current $(\mathrm{A})$, and $\mathrm{A}_{\mathrm{PV}, \mathrm{u}}$ is $\mathrm{PV}$ module area $\left(\mathrm{m}^{2}\right)$. The PV module operating efficiency has been calculated using eq. 8 .

$$
\eta_{P V}=\eta_{P V, u} \cdot \eta_{o}
$$

Where $\eta_{\mathrm{PV}, \mathrm{U}}$ is array efficiency at $1000(\mathrm{~W} / \mathrm{m} 2)$ and 25 ${ }^{0} \mathrm{C}$ and $\eta_{\mathrm{O}}$ is array efficiency due to other losses in PV (shading, dirty, Temperature, etc, $10 \%$ losses due to other losses has been considered in this study.) The total active area that is required for the PV generator $\mathrm{A}_{\mathrm{PV}}$ has been calculated using eq. 9 given as:

$$
\boldsymbol{A}_{P V}=\frac{\boldsymbol{E}_{\text {subsyst }}}{\boldsymbol{H} \boldsymbol{\eta}_{P V}}
$$

The Total PV generator Power $\mathrm{PV}_{\mathrm{MPP}}$ and the number of panels $\mathrm{N}_{\mathrm{PV}}$ that is required to supply the energy to the pumping subsystem has been determined using eq. 10 and 11 given below.

$$
\begin{aligned}
& P V_{M P P}=1000 \frac{\rho g Q H_{T D H} \eta_{P V, u}}{\eta_{P V} \eta_{s u b s y s t} H_{O P T}} \\
& P V_{M P P}=1000 \eta_{P V, u} A_{P V}
\end{aligned}
$$

$$
N_{P V}=\frac{P V_{M P P}}{P_{M P P}}=\frac{P V_{M P P}}{V_{M P P} I_{M P P}}
$$

\section{Results and Discussion}

Assuming that lack of access to clean safe water is the main cause of all the water borne related diseases in Zambia, the estimation of the average total social burden cost of the diarrheal illnesses to the country's economy is summarized in table 6. Fig.2 illustrates the projection of the diarrheal illnesses and the social burden cost per year expected to be in the future. It is worth noting that both the social burden cost and diarrheal illnesses are expected to continue increasing yearly if a anything is not done to combat the situation.

Table 6: Estimation of Social Burden Cost of Diarrheal illness

\begin{tabular}{|l|c|c|c|}
\hline \multirow{2}{*}{ Cost Description } & \multicolumn{3}{|c|}{ Year } \\
\cline { 2 - 4 } & 2010 & 2011 & 2012 \\
\hline Outpatient Cases & $1,110,338$ & $1,221,239$ & $1,238,598$ \\
\hline Outpatient Cost (\$/Patient) & 151 & 151 & 151 \\
\hline Total Outpatient Cost (\$/a) & $167,661,038$ & $184,407,089$ & $187,028,298$ \\
\hline Patient Admission Cases & 42,378 & 46,610 & 47,273 \\
\hline $\begin{array}{l}\text { Admitted Patient Cost } \\
\text { (\$/Patient) }\end{array}$ & 566 & 566 & 566 \\
\hline $\begin{array}{l}\text { Total Admitted Patient } \\
\text { Cost(\$/a) }\end{array}$ & $23,985,948$ & $26,381,260$ & $26,756,518$ \\
\hline Total Burden Cost (\$/year) & $191,646,986$ & $210,788,349$ & $213,784,816$ \\
\hline $\begin{array}{l}\text { Average Total Burden } \\
\text { Cost(\$/yr) }\end{array}$ & \multicolumn{3}{|l}{$205,406,717$} \\
\hline
\end{tabular}

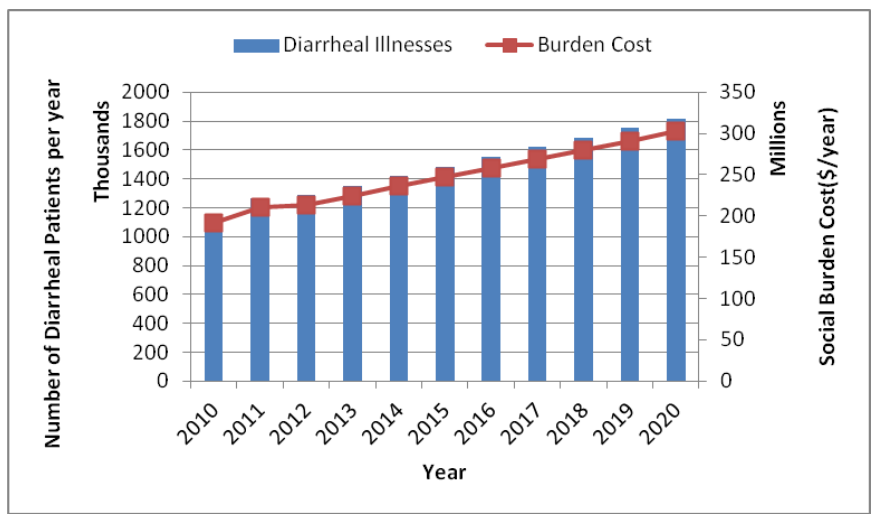

Fig. 2: Projected Social Burden Cost and Diarrheal illness cases 
There is a link between lack of access to adequate safe water supply source and diarrheal diseases. When communities do not have access to safe water sources they tend to use unclean and untreated water sources. However, with the use of solar energy technologies in water pumping system in the rural areas means access to safe clean water supply source and reduction in time spend to collect water, since the use of solar energy in water pumping system can be used to pump the water into the storage tanks for treatment and supply to the consumers. Table 7 summarizes the findings of the study and shows the social burden cost saving and potential of solar energy in water pumping technology to provide clean and reliable water source for rural communities in Zambia. According to [28] the improvements in water supply system in most cases would reduce the water borne related diseases by $30 \%$. Considering the $30 \%$ reduction in diarrheal case due to use of solar energy in water pumping systems for improved safe clean water supply to communities means saving $30 \%$ of the social burden cost. Therefore, by implementation of the solar energy technologies in water pumping systems in Zambia, the government would save approximately $\$ 61,6$ million per year from the social burden cost and be able to create direct employment of about 24,000 by employing kiosk attendants. Furthermore, it can be noticed from the analyzed results, that if these systems are used in the country a huge number of people will have access to clean safe water sources, and also both direct and indirect employment will be created which will result into boosting the economy of the communities. On the other hand, the system has short payback period of about 7 years.

Table 7: Calculation of PV Water Pumping System Costs and Saving on Social Burden Cost of Diarrheal illness

\begin{tabular}{|l|c|}
\hline Description & 2014 \\
\hline Population to be Serviced & 4.8 million \\
\hline No. of Water Serve Points & 24,000 \\
\hline No. of PV Water Pump Systems & 24,000 \\
\hline Total Water to be Pumped(m3/a) & 264.09 million \\
\hline Total Water Sell Cost (\$/a) & 66 million \\
\hline Total Power to be Installed (MW) & 36.0 \\
\hline Total Installation Cost (\$) & 360 Million \\
\hline Total Water Treatment Cost (\$/a) & 3,36 Million \\
\hline Total Maintenance Cost(\$/a) & 9,6 Million \\
\hline Average Total Burden Cost(\$/a) & 205.41 Million \\
\hline Saving on Social Burden Cost(\$/a) & 61.62 million \\
\hline Payback Period (years) & 7 \\
\hline Saving on Social Burden Cost (\$) (7yrs Period) & $431,354,105.7$ \\
\hline Employment Created & 24,000 \\
\hline
\end{tabular}

\section{Conclusion}

In this paper the water situation and diseases related to water situation in Zambia were outlined. At the same time, the potential of solar energy to contribute to improving access to safe and clean water supply source and avert the nation's water borne related disease burden has been assessed. There is a saying that's goes like 'Prevention is better than cure'. It is vital to prevent water borne related disease transmission than to cure them. This can be achieved through increasing access to safe clean water supply sources and reduction in use of untreated water from shallow wells. The analyzed results show that through improved access to safe clean water supply, the government will be able to create employment of about 24,000 people and also reduce on the social burden cost related to water borne disease by $30 \%$ which is translated to about US $\$ 61$ million savings per year. This money can be used in other development activities such as rural electrification. Therefore, the use of solar energy for water pumping systems in Zambia can greatly benefit the nation in averting the social burden costs related to water borne disease and create employment for rural communities. Furthermore, through the use of solar energy in water systems gives the government the ability to achieve four (4) of the SDGs (Sustainable Development Goals) of access to safe clean water supply source, creation of employment, and better health for the population of Zambia.

\section{Acknowledgements}

The authors are grateful to University of Zambia and Turkish Government for financial support.

\section{References}

[1] Likonge Makai, Marta Molinas (2013). Biogas-An Alternative Household Cooking Technique for Zambia", IEEE Conference, 2013.

[2] Prof. Dr. Imasiku A. Nyambe, Miriam Feilberg, ', Zambia- National Water Resources Report for WWDR3; Theme-Water in a Changing World', Repubulic of Zambia, Ministry of Energy and Water Development. Pp 6-50

[3] Index Mundi, www.indexmundi.com

[4] NWASCO, 2014,'Urban and Peri-Urban Water Supply and Sanitation Sector Report 2014', pp 2

[5] http://www.unicef.org/Zambia

[6] Chola Kasoma Mbilima, 2012, "Water Supply and Sanitation in Zambia',

[7] Ministry of Mines, Energy and Water Development of Zambia[MEWD] (2008). National Energy Policy. http://www.mewd.gov.zm/

[8] Chric Woodford, 2015, "Water Pollution: An introduction", $\quad$ June $29,2015$. www.explainthatstuff.com/waterpollution

[9] Zambia NGO water, Sanitation and Hygiene Forum, 2012, "Financing water supply and sanitation in Zambia: 2007-2012: Study to Establish Levels and Trends of Sector Financing", report 12/10/2012, pp 9-52.

[10]Lumbwe Chola and Bjarne Robberstad: Estimating average inpatient and outpatient costs and childhood pneumonia and diarrhoea treatment costs in an urban health centre in Zambia. Cost Effectiveness and Resource Allocation 2009, 7:16. 
[11]NWASCO, 2013,'Urban and Peri-Urban Water Supply and Sanitation Sector Report 2013', , pp 2

[12] S.S. Chandel, M. Nagaraju Naik, R. Chandel, 2015, 'Review of solar photovoltaic water pumping system technology for irrigation and community drinking water supplies', Renewable and Sustainable Energy Reviews 49 (2015) 1084-1099, ScienceDirect

[13] M. Benghanem, A. Hadj Arab, 2007, ' Photovoltaic Water Pumping Systems for Algeria', Desalination 209 (2007) 50-57. ScienceDirect.

[14] K.G. Mansaray, 2014, 'Optimum Design of Solar Photovoltaic Pumping Systems by Computer Simulation', International Journal of Emerging Technology and Advanced Engineering, www.ijetae.com (ISSN 2250-2459, ISO 9001: 2008 Certified Journal, Volume 4, Issue 9, September 2014)

[15] R. Posadillo, R. Lopez Luque, 2008, ‘ A sizing method for Stand-alone PV installations with variable Demand', Renewable Energy 33 (2008) 1049-1055, ScienceDirect.

[16] Yahia Bakelli, Amar Hadj Arab, Boubekeur Azoui, 2011, 'Optimal sizing of photovoltaic pumping system with water tank storage using LPSP concept', Solar Energy 85 (2011) 288-294, ScienceDirect.

[17] Tamer Khatib, 2010, 'Design of Photovoltaic Water Pumping Systems at Minimum Cost for Palestine: A Review', Journal of Applied Sciences 10 (22): 2773 2784, 2010 ISSN 1812-5654.

[18] Paul Mac Berthouex, Linfield C. Brown , 2015, 'Pollution Prevention and Control: Part II Material and Energy Balances'. pp 257-265, www.bookboon.com

[19] Abdelmalek Molceddem, Abdelhamid Midoun, D.Kadri, Said Hiadsi, Iftikhar A. Raja, 2011, 'Performance of a Directly-Coupled PV water Pumping System', Energy Conversion and Management 52 (2011) 3089-3095, ScienceDirect.

[20] A.Hamidat, B.Benyouced, 2009, 'Systematic Procedures for Sizing Photovoltaic Pumping System, Using Water Tank Storage', Energy Policy 37 (2009) 1489-1501, ScienceDirect.

[21] Tuma Nocchi Pentair Water, Electric Pumps Catalogue

[22] Ceyda Olcan, 2015, 'Multi-objective analytical model for optimal sizing of stand-alone photovoltaic water pumping systems', Energy Conversions and Management 100 (2015) 358-369, ScienceDirect.

[23] Mete Cubukcu, 2015, 'Reliability of Photovoltaic Power System Lecture Notes', Solar Energy Institute, Ege University.

[24] http://www.alibaba.com/product-detail/High-efficiencygood-price-pv solar_1824340428.html?spm=a2700.7724838.30.26.Kvg WT1\&s=p

[25] http://re.jrc.ec.europa.eu/pvgis/

[26] NWASCO, 2014," Water Supply And Sewerage Tariffs- 2014'" report

[27] http://www.alibaba.com/product-detail/solar-waterpump-invertermppt 60097638956.html?spm=a2700.7724838.29.81.SL IVyu
[28] Esrey, S.A., J.B:potash, L.Roberts and C.Shiff, 1991, Effects on Improved Water Supply and Sanitation on Ascariasis, Diarrhea, Dracunculiasis, Hookworm Infection, Schistosomiasis, and Trachoma Bulletin of the World Health Organization 695609-12.21

[29] Ahmad Agus Setiawan, Didik Hari Purwanto, Didit Setyo Pamuji, Nurul Huda, 2014, ' Development of a Solar Water Pumping System in Karsts Rural Area Tepus, Gunungkidul through Student Community Services', Energy Procedia 47 (2014) 7-14. ScienceDirect. 